\title{
Editorial
}

\section{Sayyid Qutb on the Qur'an's Artistic and Activist Dimensions}

Sayyid Qutb's reputation as one of the finest Muslim writers of all time is based on the quality of his writings in terms of their eloquence and ideas. For example, his F̌̄ Zilāl al-Qur'ān is one of the best, captivating, and most widely read Qur'anic commentaries in the Middle East. But in the West his reputation as a writer has been effectively eclipsed mainly because of political considerations. Here, he is generally portrayed as the leading ideologue for the Muslim Brotherhood or al-Qaeda. Rather than perpetuate this negative impression, this editorial seeks to highlight the literary and artistic dimensions of his Zilāl.

\section{Sayyid Qutb and His Book}

Named "Sayyid" the son of al-Hajj Qutb, he sometimes confuses many who understand Arabic and are familiar with Arab and Islamic culture, as they take his real name "Sayyid" for an epithet of reverence and leadership. Born in 1906 near Asyut in Upper Egypt, like many of his contemporaries he received a traditional village education before going to Cairo for higher education in teaching training. While teaching for about six years, Qutb also worked for Al-Ahrām and contributed to Al-Risālah and Al-Thaqāfah. He was ultimately appointed as an inspector at the ministry of education. In 1948-49, he was sent by the ministry to the United States to study teaching methods.

He returned to Egypt profoundly disenchanted with American life, ${ }^{1}$ which he criticized severely for its sexuality and promiscuity. This criticism, however, has been downplayed by the suggestion that since he never married he might have had a confused concept of American social life or experienced some kind of culture shock. After criticizing the Egyptian educational system, he resigned from his position and joined the Muslim Brotherhood, with whom he worked for about fifteen years. Imprisoned by Gamal Abdel Nasser from 1954-64 for his vocal opposition to the government, he was rearrested in 1965 and executed by hanging in 1966 - aged sixty and still a bachelor. 
A prolific author, those who view Qutb through a political and activist lens consider his much-touted Ma'älim fi al-Tari $q^{2}$ to be his most important work, for it is an in-depth political analysis and blueprint for political activism. But from an intellectual viewpoint, his Zilāl is clearly unparalleled among his works, even though it, too, may have its detractors from the religious and theological perspectives. But this latter would be just as intellectually baseless as Ibn Taymiyyah's dismissal of Fakr al-Din al-Razi's great tafsïr would be. ${ }^{3}$

As one of the best and most widely read commentaries in the Middle East, the Zilāl makes for enjoyable reading, especially if the readers have a high sense of appreciation for the Arabic language. Not only does it highlight the Qur'an's literary, artistic, and beautiful aspects, it also presents them in an equally elegant and eloquent manner. In this regard, it remains unsurpassed. It is not a traditional commentary that explains the verses one by one in order to convey their meaning(s), but one that comments on blocks of verses to reveal the themes and common messages that the Qur'an intends to convey.

The Zilāl was conceived after Qutb had written his Al-Tașwìr al-Fannī fi al-Qur' $\bar{a} n$. Hence, it is considered a continuation and expansion of Al-Tașwīr, about which Qutb explained:

Indeed, I started the research and my initial reference (marji ' $i$ al-awwal) in it (Al-Tașwìr al-Fanni fi al-Qur'ān) was the Qur'an, such that I may gather the artistic images (suwar al-fanniyah) in the Qur'an, review them, and explain how they are depicted and how artistically in sync (tanāsuq al-fannī) they are. ${ }^{4}$

\section{An Activist/Ideologue?}

Even though I am interested in Qutb's literary dimension, it has to be stated that he gave his critics all the ammunition they needed to emphasize his activist and extremist temperament. Not only did he take every opportunity offered by the Qur'an to galvanize activism, but he actually believed that such activism was part and parcel of the Qur'anic and Islamic message, one that must be pursued if one were to realize its objectives. In fact, he considers it the key to dealing (miftāh al-ta'ämul) with the Qur'an, to understanding it and perceiving its goals and objectives. ${ }^{5}$

Qutb supposedly discovered this aspect while writing his commentary on the Qur'an's last four sections (juz'/ajza '). He began to incorporate it into the earlier volumes while revising them, but was unable to complete this task before his execution. ${ }^{6}$ This is why, unlike some scholars, I believe that the activist aspect, although prominent, cannot be the Ziläl's main feature and that the literary dimension is its more original and pervasive characteristic. 
On the other hand, considering the contents of his Ma 'älim, which earned him his death sentence, his critics assert that his activist and militant postures were self-defining if not natural. ${ }^{7}$ Add to this the fact that for decades following his execution "militant" Muslims have conveniently and continuously invoked his ideas, some analysts have been led to consider him "the father of modern Islamists fundamentalism" and "the man who inspired Bin Laden."

\section{Artistic Representation (al-Tașwīr al-Fannī)}

Having acknowledged his activist dimension, I argue that scholars should focus on his literary outlook when analyzing his intellectual disposition. In an obsessive way, Qutb considers this "artistic representation" to be the "preferred

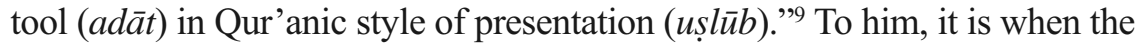
Qur'an uses

a perceptible (muhissah), dramatic and imaginary (mutakhayyilah) image to convey a mental meaning (dhihnī), psychological state (hālah nafsīyah), perceptible event, visible scene, human model (namüdhaj insānī) or human nature. Beyond this, the Qur'an would elevate the image it draws by giving it a fixed life or a renewable motion (harakah mutajaddidah). Suddenly, the mental meaning is turned into a form (hay'ah) or motion as the psychological state is projected into a screen (lawhah) or a scene (mashhad). Also, the human model becomes fixed and alive and the human nature turns into concrete (mujassamah) and visible (mar'ìyah). As for incidents (hawädith), scenes and stories, the Qur'an relates them as fixed and present (hädirah), alive and in motion. Once a conversational style (hiwarr) is added to all of this, then all elements ('anāșir) of drama and imagination are equally brought to bear. ${ }^{10}$

This description (artistic representation) is the embodiment of a literary reading of the Qur'an, which is his focus throughout the sacred text. He sees this in its stories, notices it even in the Qur'an's presentation of eschatological scenes and theological arguments, and believes that it serves as the entire sacred text's foundation. In short, it is the "preferred tool in the Qur'anic style of presentation." 11

In this regard, I am reminded fondly of 'A'isha 'Abd al-Rahman Bint alShati', a female Egyptian scholar as well as an expert of Arabic literature and Qur'an commentator, and her obsession with what she called the Qur'an's "artistic illustration" (al-bayān al-fannī). Contrary to Qutb, however, she restricts this understanding to oaths (qasam/aqsām) and a few other places in the Qur'an, seeing the artistic significance rather than theological benefits of the Qur'an's use of oaths. ${ }^{12}$ 
As Qutb elaborates and expands upon this artistic representation in his Zilāl, he readily lists them in Al-Tașwìr. Below are some examples of what he calls "mental meanings" presented in perceptible images.

1. When the Qur'an intends to stress that unbelievers will never ever attain God's pleasure nor enter paradise (a simple mental meaning), it presented that with a perceptible, tangible image by stating:

The gates of heaven will not be open to those who rejected Our revelations and arrogantly spurned them; and they will not enter the garden (paradise) until a camel passes through the eye of a needle; and this is how We punish the guilty. (Q. 7:40)

This, according to him, is "artistic representation," because the Qur'an compels one to draw a visible picture through one's imagination when he/she attempts to open the gates of heaven or visualizes them as being open. Moreover, one is asked to conjure up the image of a huge rope being threaded through a small needle (a difficult task). Except that instead of the rope, the Qur'an chooses a camel to pass through the needle's eye (an impossible task) and uses this scenario as the only prerequisite for the unbelievers to attain God's mercy and enter paradise. ${ }^{13}$ All of this is to "show," rather than simply "tell," the reader what happens to the unbelievers. In Zilall, he invites the reader to stop and visualize this "marvelous scene" (al-mashhad al- "ajīb), a scene in which a camel moves toward the needle's eye. Whenever this eye is wide open for the camel, the gates of heaven may be open for the unbelievers; whenever the camel passes through this eye, the unbelievers may enter paradise. But until these scenarios become realistic, hellfire remains their final abode. ${ }^{14}$ What an excellent and vivid depiction for a simple mental meaning.

2. When the Qur'an intends to explain that in the hereafter the unbelievers' deeds will disappear into oblivion and be of no benefit, it paints an imaginably vivid picture by stating: "And We shall turn to the deeds they have done and scatter them like dust" (Q. 25:23). Rather than informing the reader of how these deeds will simply disappear, the Qur'an creates a perceptible scene in which a powerful wind scatters them. This is done to emphasize how tangible this loss will be while portraying its potential pain, for loosing something physically visible (scattered) through a more powerful force is more painful and disappointing than loosing something that is only mentally available (invisible). In Zilāl, Qutb once again draws attention to his main focus by insisting that in the "Qur'an's usual style" (tarīqat al-Qur'ān), one's imagination is directed toward God's concrete and dramatic motion of "turning to" the deeds via having the wind blow them away, scattering them in all directions. ${ }^{15}$ 
According to Qutb, the Qur'an frequently employs such mental meanings in perceptible images. Below are two of the raw verses without analysis:

The deeds of those who reject their Lord are like ashes that the wind blows furiously on a stormy day: they have no power over anything they have gained. This is to stray far, far away. (Q. 14:18)

The only true prayer is to Him: those they pray to besides Him give them no answer any more than water reaches the mouth of someone who simply stretches out his [her] hand for it - it cannot do so: the prayers of the disbelievers are all in vain. (Q. 13:14)

This issue of AJISS opens with Farhan Mujahid Chak's "Critiquing the Modern Western Theory of Knowledge and Insights into a Qur'anic Epistemology." He compares and contrasts a western post-Enlightenment theory of knowledge with a Qur'anic epistemology and then shares insights for an alternative epistemology by discussing the features of a Qur'anic epistemology, one that begins with the affirmation or certainty of "God knowing" with the potential for "human knowing." Habib Ahmed's "The Islamization of Economies and Knowledge: A New Institutional Economics Perspective" cites examples of legal institutions in the Muslim world to argue that the Islamization of economies failed mainly due to a lack of the Islamic knowledge needed to produce the appropriate institutions and organizations.

In their "Awareness of Islam in the Post-9/11 American Workplace: A Study of Educational Instructors' Comprehension," Belal A. Kaifi and Bahaudin G. Mujtaba analyze the responses of vocational college instructors regarding Islam and Muslims. They conclude that although lacking basic knowledge about Islam, the majority of them insisted that they would treat Muslim students with sensitivity. The final article, Abdelwahab El-Affendi's "The Souls of Muslim Folk: The 'Obama Phenomenon' and the Paradoxes of Paranoid Anti-Multiculturalism," questions the celebration of Barack Obama's election as a "breakthrough" for multicultural inclusiveness. He concludes that the current xenophobic political trends that vociferously demand that Muslims should integrate are alarming.

The Forum section begins with Mazen Hashem's “The Levant: Reconciling a Century of Contradictions." It is worth noting that this paper was published in AJISS 29:2. Unfortunately, it contained several serious errors. Given the subject's significance and timeliness, we have published a well-revised version here. Bringing his insider-expert's perspective to bear, Hashem analyzes scores of issues relevant to understanding and resolving the current situation in Syria. Finally, we present Ahmad Yousif's "Interview with Zaleha 
Kamaruddin," rector of the International Islamic University Malaysia. This short article seeks to address her thoughts, style, and role, as well the challenges of being the first (and sole) Muslim woman to manage an international Islamic institution.

I hope our readers will find these papers not only thought-provoking and stimulating, but sources of inspiration and motivation for their own research.

\section{Endnotes}

1. He was a colored person, an Arab, and a Muslim. Not a good combination of qualities to have in 1940s America.

2. Other books include Al-Tașwīr al-Fannī fì al-Qur'ān, Mashāhid al-Qiyāmah fì al-Qur'ān, Al- 'Adalāh al-Ijtimā' 'ìyah fì al-Qur'ān, Al-Islām wa Mushkilāt alHad̄ārah, Al-Salām al- 'Ālamī wa al-Islām, and Al-Mustaqbal li Hadhā al-Dīn.

3. When he concluded that "it contains everything except tafsìr" (fihi kullu shay' illā al-tafsìr).

4. Sayyid Qutb, Al-Tașwìr al-Fannī fì al-Qur'ān (Cairo: Dar al-Shuruq, 2004), 9.

5. Sayyid Qutb, F̄̄ Zilāl al-Qur'ān (Beirut: Dar al-Shuruq, 1980), 4:2121.

6. Salah 'Abd al-Fattah Khalidi, Ta rī̄ al-Dārisin bi Manāhij al-Mufassirīn (Damascus: Dar al-Qalam, 2006), 604-05.

7. "Sayyid Qutb: The Pole Star of Egyptian Salafism," Perspectives on World History and Current Events, http://www.pwhce.org/qutb.html (5 August 2012).

8. Robert Irwin, "Is This the Man Who Inspired Bin Laden?" The Guardian, http:// www.guardian.co.uk/world/2001/nov/01/afghanistan.terrorism3 (5 August 2012).

9. Qutb, Al-Tașwìr, 36.

10. Ibid.

11. Ibid., 36-37.

12. 'A'isha 'Abd al-Rahman Bint al-Shati', Al-Tafsīr al-Bayānī li al-Qur'ān alKarim (Cairo: Dar al-Ma'arif, 1962), 1:15.

13. Qutb, Al-Taswìr, 38.

14. Qutb, Zilal, http://www.altafsir.com/Tafasir.asp?tMadhNo $=0 \& t$ TafsirNo $=53 \&$ $\mathrm{tSoraNo}=7 \& \mathrm{t}$ AyahNo $=40 \& \mathrm{tDisplay}=$ yes $\&$ Page $=4 \&$ Size $=1 \&$ Language $\mathrm{Id}=1(5$ August 2012)

15. Ibid., http://www.altafsir.com/Tafasir.asp?tMadhNo $=0 \& t$ TafsirNo $=53 \& t$ Sora $\mathrm{No}=25 \& \mathrm{t}$ AyahNo $=23 \& \mathrm{tDisplay}=\mathrm{yes} \& \mathrm{Page}=2 \& \mathrm{Size}=1 \&$ LanguageId $=1(5 \mathrm{Au}-$ gust 2012).

Zakyi Ibrahim

Editor

zibrahim@fullerton.edu 